


\title{
Benefits of preserving cultural heritage and its impact on providing national security in Islamic countries
}

\author{
DOI: https://doi.org/10.46398/cuestpol.3969.41
}

Zainab Etesam*

Hamideh Abdollahi **

Alireza Ebrahimi ***

\begin{abstract}
Onewayto expand social, cultural, and religious communication and interaction in Islamic societies is to preserve cultural heritage and expand the tourism industry. Considering the emphasis of religious sources on the necessity of objective and theoretical study in history and the role that this heritage plays in preserving the identity and civilization of Islamic societies, its preservation is obligatory. Therefore, one of the essential programs that should be considered in this regard is the development of laws derived from books and traditions to preserve cultural heritage. In this article, the author examines the meaning of cultural heritage, national security, the effects of preserving cultural heritage, and methods of preserving this heritage in Islamic societies, takfiri groups to destroy cultural heritage, and their study based on religious sources. One of the critical research findings is the obligation to preserve the past's cultural heritage in light of military, cultural, and economic security. The development of the tourism industry is not possible without preserving cultural heritage.
\end{abstract}

Keywords: cultural heritage; national security; tourism; takfiri groups

PhD student in jurisprudence and law, Qom University. ORCID ID: https://orcid.org/oooo-ooo17027-7759. Email: zeynabete@yahoo.com

** Assistant Professor' University of Qom' Jurisprudence and Fundamentals of Law Group. ORCID ID: https://orcid.org/oooo-0002-1459-4386. Email: h.abdollahi@qom.ac.ir

*** Assistant Professor of Qom University, Jurisprudence and Fundamentals of Law Group. ORCID ID: https://orcid.org/oooo-0003-0742-110X. Email: ali110qom@yahoo.com 


\section{Beneficios de preservar el patrimonio cultural y su impacto en la provisión de seguridad nacional en los países islámicos}

\section{Resume}

Una forma de expandir la comunicación e interacción social, cultural y religiosa en las sociedades islámicas es preservar el patrimonio cultural y expandir la industria del turismo. Considerando el énfasis de las fuentes religiosas en la necesidad de un estudio objetivo y teórico de la historia y el papel que juega este patrimonio en la preservación de la identidad y civilización de las sociedades islámicas, su preservación es obligatoria. Por lo tanto, uno de los programas esenciales que debe considerarse en este sentido es el desarrollo de leyes derivadas de los libros y las tradiciones para preservar el patrimonio cultural. En este artículo, los autores examinan el significado del patrimonio cultural, la seguridad nacional, los efectos de preservar el patrimonio cultural y los métodos para preservar este patrimonio en las sociedades islámicas, los grupos takfiri para destruir el patrimonio cultural y su estudio basado en fuentes religiosas. Uno de los hallazgos críticos de la investigación es la obligación de preservar el patrimonio cultural del pasado a la luz de la seguridad militar, cultural y económica. El desarrollo de la industria del turismo no es posible sin preservar el patrimonio cultural.

Palabras clave: grupos takfiri, patrimonio cultural, seguridad nacional, turismo

\section{Introduction}

Overall, Heritage incorporates tangible and intangible, natural and cultural, mobile and immobile, and documentary assets inherited from the past and conveyed to forthcoming generations under their priceless value. The term 'heritage' has developed substantially over time. Initially referring mainly to the impressive remains of cultures, heritage has continuously grown to adopt living and contemporary expressions.As a source of identity, heritage is a worthwhile factor in empowering local communities and permitting vulnerable societies to be involved fully in social and cultural life. Moreover, It is able to grant time-tested solutions for conflict prevention and reconciliation.

Given the rising number of international crimes associated with the looting and trafficking of cultural heritage, the initial international response was the Convention on the Means of Preventing and banning the illegal Import, Export, and Transfer of Possession of Cultural Property established by UNESCO in 197 ( UNESCO, 2018). 


\section{- Security}

The word security is one of the words that, in terms of some similarities, have a fluid, diverse and variable meaning that includes a very wide range in individual and social dimensions. Security is defined as "being safe, secure, and fearless.

Security comes from the word "safe", which crystallizes the words to calm down, not to be afraid, and not to be afraid, and in the Egyptian sense, "Security" is referred to as the attainment of security and tranquility after liberation from fear. (AL-JABARI, 2008; Crone, 2007). Safe and secure means peace of mind and eliminating fear.

With the development of human society, the concept of security went beyond the requirement of physical guarantee and, in a broader sense, was considered in political, economic, social, cultural, and even psychological dimensions (Ünver, 2016). Pourjavady has defined the word safe as the calmness of the soul to the matter and the opposite point as fear means "the soul's disgust with the matter" (Pourjavady. 2011; Farrin. 2010; Heidari, And Ghaemi, 2018). Many things have been said about the importance and necessity of security from the infallible (PBUH).

As the definition of national security implies, national security includes components of national authority, and the heritage of each country is one of the components of that country's national authority; therefore, the necessary efforts should be made to identify and transfer this heritage and protect it.

\section{- Heritage}

Shahid second says in this regard: Inheritance is based on the weight of the passive and was originally inherited because the preposition "V" was preceded by a broken heart (Sharifi Pour \& Shouri. 2019). Inheritance in legal terms is "the transfer of ownership of the deceased's property, after his death to his heir."

Inheritance in legal terms is "the transfer of ownership of the deceased's property, after his death to his heir." (Timothy. 2011; Borhani Kakhki, et al., 2021). In the present discussion, inheritance does not have the meaning used in jurisprudence and law, that is, inheritance, but this word is always inherited and often associated with the word culture, and its equivalent word in Arabic is the word "inheritance".

The inheritance includes all instances and manifestations of material, spiritual, tangible, and intangible; cultural heritage means cultural heritage; that is, a culture that with all its manifestations is inherited from previous generations to later generations and forms the social elements of the new generation (Stylianou et al., 2015; Rohmansyah, 2019). 


\section{- Culture}

In a comprehensive definition, culture is a collection of human creations and ideas created by man and his separation from nature and the means of his superiority over other creatures. Thus, culture includes all material tools and what is made by man from natural matter, Methods and processes of their construction (material culture) All values, views and beliefs, ideas, knowledge, techniques, religion, customs and traditions, science, philosophy, literature, art and all the mental products of man (spiritual culture). In other words, culture includes the material and spiritual elements of social life in which human beings are born and raised in this way, something called cultural identity is given to the individual or human group; This identity provides the means of distinguishing man from other races and tribes. (Ünver, 2016).

Historical and cultural property is a mirror of a nation's past. These works, especially the works of distant eras that lacked the traditional means of transmitting culture and message, such as books and calligraphy, are considered to be the revealing document of the life of that time. "And perhaps a seemingly worthless broken pottery, or a dying inscription, ignites a corner of the social behavior or science and civilization of its predecessors (Schmallegger and Carson, 2010: 59).

Human societies today are faced with the term cultural security; the protection of individual culture and society from any attack and threat is called cultural security. In other words, cultural security includes creating a safe, calm, and free from any threat that human beings have prepared to religion and thoughts, ethics, customs, beliefs and values, cultural heritage, literary works, and so on. Due to the role and position of culture in human identity and existence and the development of human societies, and also because of the widespread and effective influence of culture on all aspects of human life, both individual and collective, material and spiritual, spiritual and physical, as well as the impact that cultural issues have on other sectors providing cultural security is more sensitive. Accordingly, cultural promotion increases social security and, consequently, economic and political security, Therefore, the first step in ensuring the security of individuals is to ensure cultural and psychological security (Hawkins \& Mann. 2007).

\section{Cultural heritage in domestic and international law}

At first glance, cultural heritage means all the works that have been passed down from generation to generation. In this definition, cultural heritage refers to the material works leftover from the past, and in fact, includes only tangible and objective works. In addition, it is limited to historical monuments, while we also have an intangible part, such as beliefs, traditions, local languages and dialects, and religious traditions and rituals. 
Cultural heritage is used in two general and specific meanings. In the general sense, it refers to what has been the result of the thoughts, beliefs, and efforts of previous generations of society and nation, which have crystallized in the form of beliefs and customs or traditions or handicrafts and have been passed on to future generations. Which may include material works, such as buildings and objects, or immaterial works, such as customs, traditions, and beliefs. ( Sharp \& Leiboff. 2015).

In a special sense, material works are called cultural heritage. This is a special concept that is discussed in jurisprudential and legal issues, so they are also called cultural-historical works. Here are two definitions of cultural heritage in domestic law: "Article 1 of the Law on the Preservation of National Monuments and Article 1 of the Statute of the Cultural Heritage Organization.

a) Article 1 of the Law on Preservation of National Monuments: All industrial monuments, buildings, and places that were built in Iran until the end of the Zandiyeh dynasty, both movable and immovable, can be considered as national monuments of Iran and placed under the protection and supervision of the government (Frigo, 2004).

b) Article 1 of the Statute of the Cultural Heritage Organization of the country: cultural heritage includes remnants of the past that represent human movement throughout history, and by identifying it, the ground for recognizing his identity and preserving his cultural movement is made possible, and through this, the grounds for learning are provided for human beings (Frigo. 2004). We follow the definitions of cultural heritage by looking at international law; the most comprehensive definition of cultural heritage was presented at the Seventeenth Session of the General Conference of the United Nations Educational, Scientific and Cultural Organization, adopted on 16 November 1972 in Paris. It is limited to some examples of cultural heritage. Article (1) of this contract states:

Article 1: For the purposes of this Convention, the following shall be deemed cultural heritage:

\section{- Effects:}

Architectural, sculptural, or painting works on buildings, elements, and buildings that have an ancient aspect, inscriptions, caves, and a combination of factors that have exceptional universal value in terms of history, art, and science;

\section{- Collections:}

A collection of separate buildings or complexes that are of exceptional historical, artistic, and scientific historical value in terms of architecture, uniqueness, or their dependence and time in a natural landscape; 


\section{- Areas:}

Human works or works created by man and nature together as well as areas including archeological sites that have a unique global value in terms of history, aesthetics, ethnography or anthropology in Iran; This definition, in turn, is a complete and comprehensive definition, but the disadvantage of this definition is that it does not state a specific criterion for recognizing the existence of exceptional value in a particular work, and this is left to the discretion of the International Cultural Heritage International Committee ( Frigo. 2004).

\section{Cultural heritage interests in Islamic countries}

\subsection{Development of tourism industry}

One of the issues related to the protection of cultural heritage and the existence of security is the development of a tourism development strategy. The prosperity and development of tourism depend on security. Lack of comprehensive planning and development in the tourism industry in all dimensions depends on the existence of an effective factor of security; tourism development is not possible without preserving cultural heritage from destruction.

The United Nations defines a tourist as follows: Who is to entertain tourists visited scenic spots, medical, business, sports, or pilgrimage, to a place other than the place where it resides travels, Provided that the minimum length of stay less than 24 hours and not more than six months, and tourism is: "Optionally spending some of his leisure time in a place other than a permanent residence in order to enjoy the pleasures of tourism" (Quoted by: Norouzi. 2010: 154).

\subsection{The role of cultural heritage in attracting religious tourists in Islamic countries}

Religious tourism has been one of the most prosperous and ancient tourism in the past and now around the world. Ancient Greek holy ceremonies in the temples of Apollo, Egyptian expeditions to visit the pharaohs, and Iranian religious rites in the temple of Anahita in Kangavar all indicate the antiquity of religious tourism among various nations (Heydari et al., 2018). In recent decades, on the one hand, due to machine life and the need for spirituality in life, and on the other hand, facilitating travel by expanding means of transportation, travel to meet spiritual needs has expanded rapidly in the world. In 2000 , two hundred and forty million people traveled for this purpose, and $29 \%$ of the world's travel was religious. 


\section{2 \\ Zainab Etesam, Hamideh Abdollahi y Alireza Ebrahimi \\ Benefits of preserving cultural heritage and its impact on providing national security in Islamic}

In 1979, the first conference was held on how to manage sacred places and maintain religious shrines in the face of globalization.

The existence of holy shrines in Islamic countries and the diversity of geographical environment and social, economic, and cultural conditions create religious tourism. However, studies show that the 57 Islamic member states of the Organization of the Islamic Conference, with a population of about 1.5 billion (23\% of the world's population), have only $12 \%$ of the world tourism market. Among these countries, $82.5 \%$ of tourist attraction is in possession of 10 Islamic countries and about $10 \%$ of global tourism revenue (Heydari et al., 2018).

Due to its special cultural situation and the existence of 9,0oo historical religious shops, Iran can be a destination for Muslim tourists in Islamic countries, as well as the existence of antiquities of other religions, for nonMuslims, one of the world's tourist destinations. The need to learn from the works of the past the lesson on the weight of the verb is from the root "abar" which has various meanings Such as it comes down to interpreting, measuring, passing and surprising.

In fact, a lesson is a state that arises for human beings because of dealing with outward matters and leads to esoteric knowledge. The similarity of human beings' lives and different ethnic groups with each other and the current traditions in human life make this educational method effective. Gaining insight, benefiting from the experiences of others, being relatively immune to error, and understanding that human beings are mortal and that what they provide in this world is transferable.

One of the most famous jurisprudential rules that document many jurisprudential issues. It is a harmless rule that can be used in the discussion of protection and non-destruction of cultural heritage, because the provisions of this rule are general and include material and spiritual losses. Therefore, in the present era, when we are witnessing countless benefits of cultural heritage from different scientific, economic, and spiritual perspectives, etc., explaining this rule and using it can determine many aspects of the importance of these works for us. According to this rule, the damage is prohibited. In most contemporary legal systems, this issue is referred to as "not being licensed to abuse the right." and it can be said that apart from the numerous Shari'ah rulings that can be considered as evidence of this rule, the ugliness of harm and the good of preventing it, and consequently the prohibition of harms, are rational rulings and rational documents (Harstad \& Selten, 2013).

An examination of the cases of use, loss and damage in Islamic sources shows that the loss includes all material and spiritual losses and damages, just as this word has been used in the case of lack of respect and reputation. 
The meaning of intellect and nature on preserving the cultural heritage of the past Humans, regardless of their customs and rituals, do not consider it permissible to insult the dead, and this is disgusting to all people, and they are not even willing to insult ordinary graves and always express their protest in different ways. Therefore, insulting the dead is against human nature. Now the sensitivity of this issue about the graves of elders and scholars is multiplied; the rulings of the dead in Islamic jurisprudence show the same bow and respect that Islam gives to the dead. The rules of ablution, shrouding, embalmment, prayer, funeral, burial, and much other admirable show the respect that Islam has for human beings. This is not for Muslims; Relatives who burn their dead in religious ceremonies also consider it a form of respect for the dead. Those who bury a corpse after hundreds of years do not allow disrespect to its grave.

The graves of the prophets, saints, and righteous servants of God have always been of interest to the people, and their obstinacy towards them was prevented in any way. One of the ways to maintain the respect of the tombs of the elders has been to build buildings, courtyards, and minarets on their holy tombs throughout history. In fact, building on graves is one of the ways to attract people's attention to these places and use them for divine nearness.

\section{Methods of preserving tangible and intangible cultural heritage}

One of the most important activities for the preservation of antiquities in their care measures in order to prevent their deterioration and destruction; in fact, care includes all activities that preserve cultural and natural life. With the aim of presenting the basic and artistic messages that cultural heritage offers to those who use them or look at them with amazement. (Hendijani et al., 2014).

Conservation and maintenance have two aspects, positive and negative aspects. The meaning of protection of positive aspects is to be able to provide the conditions for the survival of cultural monuments in society today and in the future. Negative maintenance is concerned with combating erosive factors.

The two are different in not only cognition; among other things, the fight against erosion factors of continuity also provides an effective, and this issue is important here from this perspective. That cultural heritage has a physical and external aspect and has a value and message, and in fact has a kind of social life (Stylianou et al., 2015). 
In fact, the emphasis is on preserving the spirit and meaning of cultural heritage along with its objectively visible body. Our religious sources mention several ways to protect material works. Repair of an ancient building Long-term preservation and preservation of antiquities in the true and scientific sense is much more expensive than the construction of monuments. One of these ways is the restoration of historical monuments, which is very important to conduct basic and applicable research in this area to protect the monuments.

Restoration means performing all the actions done to modify the existing materials and the structure of cultural work to return it to its original known position. The purpose of restoration is to preserve and reveal the artistic and historical values of the work and is based on attention to the remaining original parts and evidence of the original condition of the work.

\section{The importance of the museum in preserving antiquities}

A museum is a place where related objects and materials are collected, studied, and stored, then exposed to the public for the purpose of education, dissemination of information and entertainment. The museum is in fact a reflection of all human activities from their natural, cultural, and social environment.

Due to the growing importance of preserving Persian historical monuments - Iran also needs to create modern museums that can display the nation's history, culture, and identity with the culture and civilization of Iran to achieve international standards for the protection of antiquities. In this regard, it is necessary for the Cultural Heritage and Tourism Organization to make more efforts and create a central museum in each city, equipped with valuable works of historical periods.

In fact, the purpose of museums is to research the relics and evidence left by man and his environment. Collecting these works and spiritual productivity and creating a connection between these works and especially displaying them in order to study and spiritual benefit. Creating and preserving a museum means paying attention to the history and civilization of your nation and country. Of course, it is not possible to keep all the works in the museum; Like the historic houses, we have more than one million historic houses in the country, of which only thirty-two thousand have been identified, and the rest of the buildings are kept in non-standard conditions.

Zakaria in Halab, Yahya in sham, Shoaib in Jordan, sheyth in Lebanon, and the tombs of other Islamic lands' prophets, on which strong buildings have been built (Barasheed et al., 2014). Here are some narrations about 
the Muslim way of life in building tombs to preserve the status of the tomb owner and protect cultural heritage:

1. It is narrated that when Prophet Ibrahim (AS) completed the rites of Hajj, God commanded him to go, in the meantime, the mother of Ishmael (AS) passed away. Ishmael buried him next to the house of the Ka'bah and built a Hajar wall around it so that his grave would not be insulted.

2. Mu'awiyah Ibn Ammar quotes Imam Sadegh (AS) as saying: Seventy prophets have been buried between the pillar of Yemen and the hajar_all_aswad, who have died of severe hunger and hardship.

\section{Conclution}

According to these narrations and the numerous narrations that have been narrated in the books of the narrations of the two sects, we reach a conclusion that:

1. The ancients and Islamic scholars' tradition to the tombs and the construction of tombs to honor the owner of the tomb and honor him.

2. Protecting graves from destruction is possible only in the shadow of building them and developing the tradition of pilgrimage and regular visits to these religious and spiritual monuments.

What has been repeatedly stated in the narrations is meeting and attending the holy observation due to the continuation of the tradition of learning and awakening of the human heart.

3. Registering a work in the list of national works

Given the abundance of works in a community and the lack of facilities to maintain and maintain all of them, prioritizing works can be the most important way to register a work in the list of national works. Prioritization should be in accordance with the various values of historical monuments in society, including cultural-religious-economic, social, and scientific values.

In this regard, according to the Holy Quran's goals in preserving and protecting cultural heritage and the values, lessons, and awakening of conscience and feelings of human beings, should also be considered. In addition to these environmental conditions, the effects and factors that cause premature destruction of the work, including natural disasters, must also be considered. 
Zainab Etesam, Hamideh Abdollahi y Alireza Ebrahimi

676

Benefits of preserving cultural heritage and its impact on providing national security in Islamic countries

\section{Bibliographic References}

AL-JABARI, A.R.Y. 2008. Reasons for the possible incomprehensibility of some verses of three translations of the meaning of the Holy Quran into English (Doctoral dissertation, University of Salford).

BARASHEED, Osamah; RASHID, Harunor; ALFELALI, Mohammad; TASHANI, Mohamed; AZEEM, Mohammad; BOKHARY, Hamid; KALANTAN, Nadee. 2014. "Viral respiratory infections among Hajj pilgrims in 2013” In: Virologica Sinica. Vol. 29, No. 6, pp. 364-371.

BORHANI KAKHKI, Maryam; NARIMANI, Mohammad; MOUSAZADEH, Tavakkol. 2021. "The effectiveness of cognitive behavioral couple therapy on the quality of life and marital satisfaction of uncompromised divorce applicants" In: Women and Family Studies. Vol. 13, No. 50, pp. 212-239.

CRONE, Patricia. 2007. "Quraysh and the Roman army: Making sense of the Meccan leather trade" In: Bulletin of the School of Oriental and African Studies. Vol. 70, No. 1, pp. 63-88.

HAWKINS, Donald E; MANN, Shaun. 2007. “The World Bank's role in tourism development” In: Annals of Tourism Research. Vol. 34, No. 2, pp. 348363 .

HEYDARI CHIANEH, Rahim; DEL CHIAPPA, Giacomo; GHASEMI, Vahid. 2018. "Cultural and religious tourism development in Iran: prospects and challenges" In: Anatolia. Vol. 29, No. 2, pp. 204-214.

HEIDARI, Zohre; GHAEMI, Morteza. 2018. "The equivalent of the cultural element of clothing in the Holy Qur'an based on Newmark's theory" (A case study of five Persian translations of Holy Quran: Ayati, Bahrampour, Fouladvand, Mojtabavi, and Makarem Shirazi)" pp. 79-106.

HENDIJANI, Fatemeh; SADEGHI-ALIABADI, Hojjat; HAGHJOOY JAVANMARD, Shaghayegh. 2014. "Comparison of human mesenchymal stem cells isolated by explant culture method from entire umbilical cord and Wharton's jelly matrix" In: Cell and Tissue Banking. Vol.15, No. 4, pp. $555-565$.

STYLIANOU, Neophytos; BUCHAN, Iain; DUNN, W. 2015. "A review of the international Burn Injury Database (iBID) for England and Wales: descriptive analysis of burn injuries 2003-2011" In. BMJ open. Vol. 5, No. 2, pp. 12-39.

FARRIN, Raymond K. 2010. "Surat al-Baqarah: A Structural Analysis" In: The Muslim World 100. Available online. In: https://www.academia. 
edu/8642515/Surat_al-Baqarah_A_Structural_Analysis. Date of consultation: 15/12/2020.

FRIGO, Manlio. 2004. "Cultural Property v. Cultural Heritage: A battle of concepts in international law? In: Int'l Rev. Red Cross. No. 86, pp. 367399 .

HARSTAD, Ronald M; SELTEN, Reinhard. 2013. "Bounded-rationality models: tasks to become intellectually competitive" In: Journal of Economic Literature. Vol. 51, No. 2, pp. 496-511.

NOROUZI, Aghdam M. 2010. "Survey Of Social-Behavioriour Abnormal In Students” In: Islamic Azad University (2 Region), pp. 199-226.

POURJAVADY, Reza. 2011. Philosophy in Early Safavid Iran: Najm Al-D? n Ma? m? d Al-Nayr? z? and His Writings. Vol. 82, No. 144, pp. 115-132.

ROHMANSYAH, Rohmansyah. 2019. "Critical Analysis on the Thoughts of Ibn Jarir al-Tabari about Jilbab in the Quran Surah al-A $\square$ zab Verse 59" In: Millati: Journal of Islamic Studies and Humanities. Vol. 4, No. 2, pp. 117136.

SCHMALLEGGER, Doris; CARSON, Dean. 2010. "Is tourism just another staple? A new perspective on tourism in remote regions" In: Current Issues in Tourism. Vol. 13, No. 3, pp. 201-221.

SHARIFI POUR, Feysal; SHOURI, Fatemeh. 2019. "The Position of Trial Interruption in Khamsah (five) Religions by Emphasizing Verses and Traditions” In: Quarterly Sabzevaran Fadak. Vol. 9, No. 36, pp. 171-201.

LEIBOFF, Marett; SHARP, Cassandra. 2016. "Cultural legal studies and law's popular cultures” In: Cultural legal studies: Law's popular cultures and the metamorphosis of law, pp. 3-28.

TIMOTHY, Dallen J. 2011. Cultural heritage and tourism: An introduction. Vol. 4. Channel View Publications. Available online. In: https://doi. org/10.21832/9781845417727. Date of consultation: 15/12/2020.

UNESCO, United Nations Educational, Scientific and Cultural Organization. 1970. Available online. In: https://ich.unesco.org/en/convention. Date of consultation: 15/12/2020.

ÜNVER, H. Akın. 2016. "Schrödinger's Kurds: Transnational Kurdish geopolitics in the age of shifting borders" In: Journal of International Affairs. Vol. 69, No. 2, pp. 65-100. 

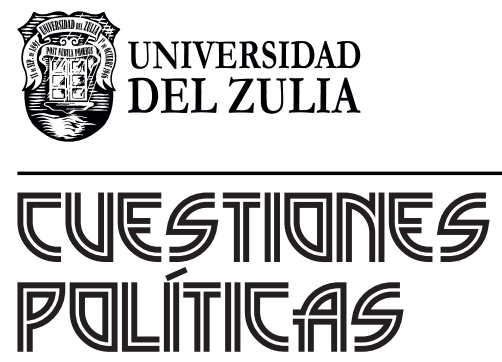

Vol.39 No 69

Esta revista fue editada en formato digital y publicada en julio de 2021, por el Fondo Editorial Serbiluz, Universidad del Zulia. Maracaibo-Venezuela 